KESESUAIAN LAHAN TANAMAN JENGKOL (Archidendron $s p$.) \& PETAI (Parkia sp.) DI KABUPATEN WAJO, SULAWESI SELATAN

\title{
LAND SUITABILITY ASSESSMENT OF JENGKOL (Archidendron sp.) \& PETAI (Parkia sp.) AT WAJO DISTRICT, SOUTH SULAWESI PROVINCE
}

\author{
Ari Raharjo \\ Universitas Gunadarma, Jakarta, Indonesia \\ email: ariraharjo@staff.gunadarma.ac.id
}

Diterima: 20 Juni 2019

Disetujui: 28 Agustus 2019

\begin{abstract}
ABSTRAK
Jengkol dan petai merupakan tanaman hortikultura penting bagi masyarakat. Pada musim-musim tertentu, harga komoditi ini mencapai harga tinggi sekali. Wilayah produksi terbesar dari dua komoditi ini terletak di Sumatera dan Jawa. Sedangkan Sulawesi dan Indonesia bagian Timur relatif sedikit sekali. Penelitian ini bertujuan untuk menganalisa kesesuaian lahan di Sulawesi (Kabupaten Wajo) terhadap tanaman jengkol dan petai. Metode penelitian ini adalah survey lapangan dan analisa laboratorium terhadap 2 sampel tanah (mini pits) di bagian Utara dan Selatan lokasi penelitian. Parameter yang diukur adalah suhu, curah hujan, kelembaban, drainase, tekstur, bahan kasar, kedalaman tanah, ketebalan \& kedalaman gambut, KTK, kejenuhan basa, pH, C-organik, salinitas, alkalinitas, kedalaman sulfidik, lereng, bahaya erosi, genangan, batuan di permukaan dan singkapan batuan. Kesimpulan dari penelitian ini menunjukan bahwa lahan di Desa Lempong, Kecamatan Bola ini mempunyai tingkat kesesuaian lahan Sesuai Marjinal (S3) dengan faktor pembatas tekstur dan kedalaman tanah terhadap tanaman jengkol dan petai.
\end{abstract}

Kata kunci: jengkol, kesesuaian lahan, petai, Wajo

\section{ABSTRACT}

Jengkol and petai are important horticultural crops for the community. In certain seasons, the price of these commodies reach very high. The largest production area are located in Sumatra and Java. Whereas Sulawesi and Eastern Indonesia are relatively few. This study aims to analyze the suitability of land in Sulawesi (Wajo Regency) for jengkol and petai plants. This research used a field survey and laboratory analysis of 2 soil samples (mini pits) in the North and South areas. The parameters measured are temperature, rainfall, humidity, drainage, texture, rough material, soil depth, peat thickness \& depth, Cation Exchange Capacity, base saturation, pH, C-organic, salinity, alkalinity, sulfidic depth, slope, erosion hazard, inundation, surface materials and rock outcrops. The conclusion of this study shows that the land in Lempong Village, Bola Subdistrict has Marginal (S3) land suitability with texture and soil depth limiting factors.

Keywords: jengkol, land suitability, petai, Wajo

\section{PENDAHULUAN}

Geografi Indonesia memberikan keunggulan komparatif bagi pertumbuhan keanekaragaman tanaman hortikultura. Produksi sayuran, buah-buahan, tanaman hias dan tanaman biofarmaka pada tahun 2017 masing-masing mencapai 12,4 juta ton, 19,64 juta ton, 819,32 juta ton dan 488,54 juta ton. Pertumbuhan produksi tanaman sayuran dari tahun 2016 ke tahun 2017 mencapai 3,32\%; buah-buahan 7,10\%, dan tanaman hias 7,36\% (Kementerian Pertanian, 2019). Saat ini, komoditas hortikultura yang potensial dikembangkan oleh pemerintah sebanyak 323 komoditas. Komoditas tersebut terdiri atas buah-buahan sebanyak 60 jenis, sayuran sebanyak 80 jenis, biofarmaka sebanyak 66 jenis dan tanaman hias sebanyak 117 jenis.

Jengkol adalah salah satu komoditi penting hortikultura di Indonesia. Produksi nasional komoditas ini mencapai $66.064,80$ ton di tahun 2017 dan pada musim-musim tertentu, harga komoditi ini dapat melonjak tinggi (Cipto, 2019). Selain jengkol, petai juga merupakan komoditi hortikultura penting di Indonesia. 
Produksi komoditas ini mencapai 213.356,20 ton pada tahun 2017, sekitar 3,23 kali produksi jengkol. Pada musim-musim tertentu, komoditas ini juga mempunyai harga yang relatif tinggi sekali (Wanto, 2019).

Berdasarkan data statistik, secara geografi, produksi kedua komoditas tersebut berada di wilayah bagian Barat dan sebagian wilayah Tengah Indonesia. Wilayah tersebut adalah Jawa, Sumatera dan Kalimantan. Produksi petai di Jawa dan Sumatera masing-masing mencapai $82,44 \%$ dan $13,69 \%$ dari produksi nasional. Sedangkan untuk jengkol di Jawa dan Sumatera, masing-masing $25,51 \%$ dan $57,43 \%$ dari produksi nasional. Untuk wilayah Sulawesi dan wilayah Timur lain menunjukan tingkat produksi yang rendah sekali (Kementerian Pertanian, 2019).

Kabupaten Wajo adalah salah satu Daerah Tingkat II di propinsi Sulawesi Selatan. Ibu kota kabupaten tersebut adalah Sengkang. Luas wilayah kabupaten ini mencapai 2.056,19 $\mathrm{km}^{2}$ dan berpenduduk sebanyak kurang lebih 400.000 jiwa. Pada Kabupaten Wajo, potensi hortikultura terbesar berada pada tanaman sayuran dengan luas panen terluas tahun 2017 adalah cabai rawit yaitu 707 hektar, dengan produksi mencapai 4.913 kuintal. Sementara itu, produksi buah-buahan terbesar adalah pisang yaitu sebesar 275.694 kuintal (BPS Kabupaten Wajo, 2018). Di dalam pokok-pokok program kerja Pemda Kabupaten Wajo yang tercantum di dalam visi misi 2014-2019 dan Rencana Tata Ruang Wilayah (RTRW) Tahun 2012 - 2032 tercantum program pengembangan tanaman hortikultura. Tanaman petai dan jengkol adalah beberapa tanaman hortikultura yang termasuk di dalam program ini. Namun, berdasarkan statistik kabupaten Wajo, tanaman petai dan jengkol tidak tercatat sebagai tanaman hortikultura penting walaupun di Makasar komoditi ini dijual dengan harga relatif mahal (Cipto, 2013). Banyak faktor yang menyebabkan kedua tanaman ini belum mempunyai peranan penting. Salah satu faktor penyebab adalah kesesuaian lahan.

Berdasarkan uraian di atas maka penelitian ini bertujuan untuk mengetahui kesesuaian lahan di Kabupaten Wajo untuk pengembangan tanaman petai dan jengkol.

\section{METODE PENELITIAN}

Survey dilakukan pada bulan Februari 2019. Lokasi penelitian adalah Desa Lempong, Kecamatan Bola, Kabupaten Wajo, Propinsi Sulawesi Selatan. Metode yang digunakan dalam penelitian ini adalah survey lapangan dan analisa sampel tanah dan air.

Untuk mendapatkan data karakteristik lahan dilakukan pengamatan pada profile pits dengan membuat 2 mini pits (sampel). Satu pits di bagian Utara dan satu di bagian Selatan. Untuk mencapai kedalaman $120 \mathrm{~cm}$, pada dasar mini pit dibor dengan menggunakan bor belgie sampai kedalaman $120 \mathrm{~cm}$. Untuk mengetahui karakteristik kimia tanah telah dilakukan pengambilan contoh tanah pada lapisan atas (top soil, 0-20cm) dan lapisan bawah (sub soil 40-60 $\mathrm{cm})$.

Beberapa parameter yang diukur dalam analisa tanah dan air ini adalah: drainase, tekstur, bahan kasar, kedalaman efektif, kematangan gambut, ketebalan gambut, KTK tanah, Kejenuhan Basa (KB), pH tanah, $\mathrm{C}$ organik, Total $\mathrm{N}, \mathrm{P}_{2} \mathrm{O}_{5}, \mathrm{~K}_{2} \mathrm{O}$, salinitas, alkalinitas, kedalaman sulfidik, lereng, batuan di permukaan, singkapan batuan, bahaya longsor, bahaya erosi dan genangan. Analisa tanah dan air ini dilakukan di laboratorium terakreditasi yaitu laboratorium BPTP Balitbangtan, Sulawesi Selatan.

\section{HASIL DAN PEMBAHASAN}

Lokasi penelitian terletak pada ketinggian $45 \mathrm{~m}$ dpl dengan suhu rata-rata tahunan $28,5^{\circ} \mathrm{C}$. Di Kabupaten Wajo terdapat 10 stasiun iklim yang dapat digunakan untuk menjelaskan kondisi iklim. Dari 10 stasiun iklim tersebut hanya satu stasiun yang dapat digunakan untuk menjelaskan kondisi iklim di lokasi penelitian. Stasiun tersebut adalah Stasiun Peneki, yang terletak pada koordinat 120,00 BT dan 4,17 LS (berjarak paling dekat dengan lokasi penelitian).

Rekaman data iklim selama 30 tahun dari stasiun Peneki menunjukkan bahwa curah hujan tahunan rata-rata di lokasi penelitian adalah $1.806 \mathrm{~mm}$ dengan bulan basah sebanyak 3 bulan dan bulan kering sebanyak 3 bulan juga. Dengan kondisi iklim seperti itu, maka lokasi penelitian masuk dalam Zona Agroklimat D2 menurut klasifikasi Oldeman, yaitu daerah beriklim kering. 
Lokasi studi berada pada landform dataran tektonik dengan bahan induk penyusun berupa batuliat dan batu pasir pada relief berombak (lereng 3-8\%). Pengamatan visual di lokasi menunjukkan ada beberapa tanaman keras yang tumbuh. Beberapa tanaman keras tersebut antara lain adalah trembesi, jambu mete, cempedak, bambu, mangga, nangka, petai cina, dan kelapa. Pertumbuhan tanaman-tanaman tersebut terlihat kurang baik dan produksi buah yang dihasilkan kurang optimal. Pada lahan sekitar tanaman tersebut banyak ditemui pematang sawah yang saat survey dilakukan sedang berada pada masa tidak tanam.

Sumber air di lokasi studi berasal dari air tadah hujan dan juga sumber air dari air tanah dangkal. Air permukaan terletak kurang lebih 3 $\mathrm{km}$ dari wilayah penelitian, berupa rangkaian rawa-rawa belakang (back swamp) dari sungai Walanae.

Hasil pengamatan pada sample 1 (bagian Utara kebun) menunjukan bahwa lahan mempunyai lapisan kedap yang sedang, yaitu antara kedalaman 60-65 cm dari permukaan tanah. Hasil deskripsi penampang tanah sample ini tersusun dalam 4 (empat) horizon (Gambar 1) dengan sifat masing-masing horizon diuraikan sebagai berikut:
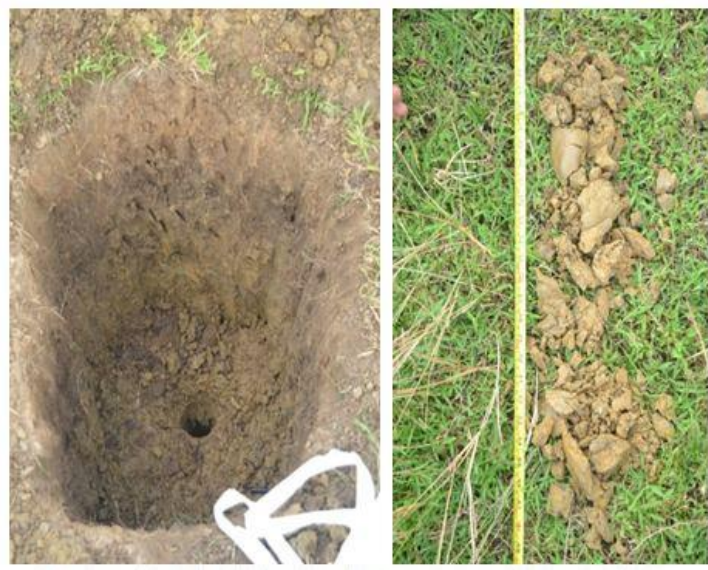

Gambar 1. Mini Pits Sampel Bagian Utara
- A1 (0-20) cm; kelabu kemerahan (2.5YR 5/1); lempung liat berpasir (sandy Clay loam); gumpal; agak lekat (basah); akar halus sedikit; pori halus sedikit; $\mathrm{pH}$ 6,7 (netral); horison baur; dengan bercak merah terang (2,5YR6/8), tidak ada fragmen.

- A2 (20-40) cm; merah kekuningan (5YR4/1); lempung berdebu (silty loam); massive; lekat; perakaran jarang; pori halus sedikit sekali; horison tegas datar; tidak ada bercak dan fragmen.

- A3 (40-60) cm; warna kuning kemerahan (5 YR6/6); tekstur lempung berpasir; konsistensi basah agak lekat; konsistensi lembab masive; akar tidak ada; pori halus sangat sedikit; $\mathrm{pH}$ 6,32 (agak masam); horison tegas datar; bercak kuning merah terang (2,5 YR 6/8), tidak ada fragmen.

- B (60-120) cm; kuning kemerahan (5YR 6/6); tekstur liat berpasir (sandy clay); masisive; agak lekat; tidak ada perakaran; pori halus sedikit; pH 6.5; bercak banyak warna merah terang $(2,5$ YR6/8).

Sedangkan tanah pada sample 2 (bagian Selatan kebun) mempunyai lapisan kedap yang dangkal, yaitu pada kedalaman $65 \mathrm{~cm}$ dari permukaan tanah. Hasil deskripsi penampang tanah sample ini tersusun dalam 4 horizon juga (Gambar 2) dengan sifat masing-masing horizon diuraikan sebagai berikut: 

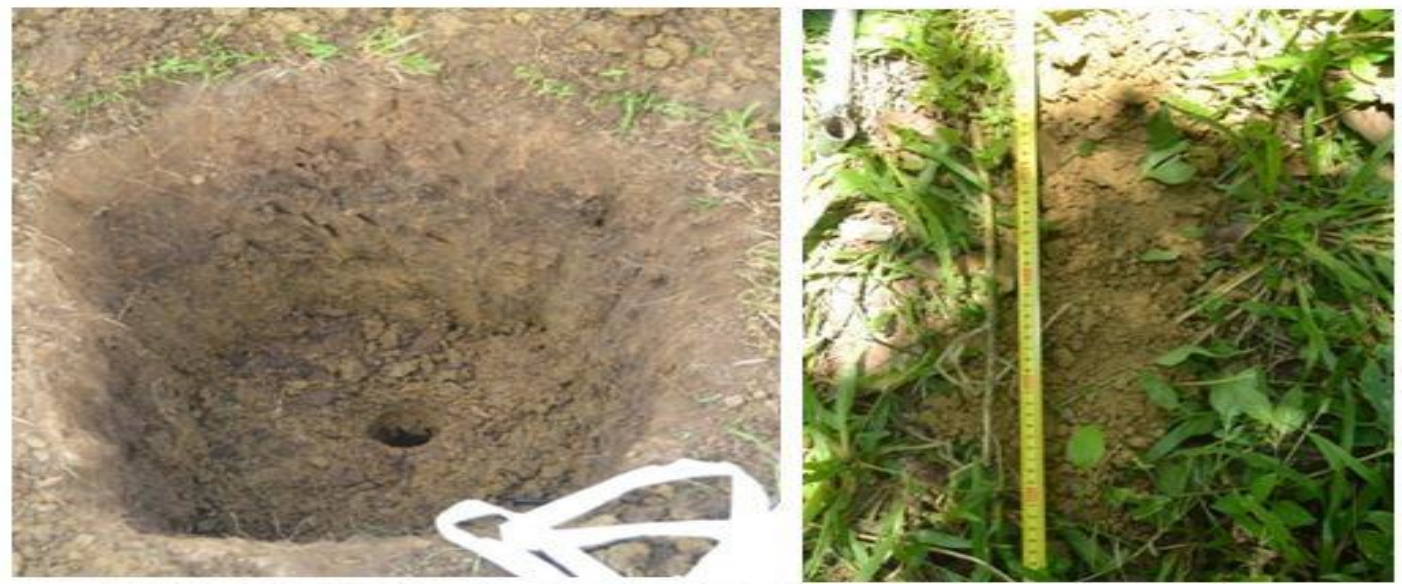

Gambar 2. Mini Pits Sampel Bagian Selatan

- A1 (0-14) cm; kelabu gelap (5YR 4/1); lempung liat berpasir (sandy clay loam); remah (lembab); agak lekat (basah); drainase baik; akar halus sedikit; pori halus sedikit; $\mathrm{pH}$ 5,58 (AM); horison tegas datar; tidak ada bercak dan fragmen.

- A2 (14-27) cm; kelabu (grey) (5YR5/1); lempung berpasir(sandyloam); massive; agak lekat; perakaran jarang; pori halus sedikit sekali; horison tegas datar; bercak kuning kemerahan (5YR 7/6), tidak ada fragmen.
- A3 (27-65) cm; warna kuning kemerahan (5 YR6/6); tekstur lempung berpasir (sandy loam); konsistensi basah lekat; konsistensi lembab sangat masive; akar tidak ada; pori halus sangat sedikit; $\mathrm{pH} 5,42$; horison tegas datar; bercak kuning kemerahan (5 YR 5/1), tidak ada fragmen.

- B (65- 120) cm; kuning kemerahan (5YR 7/8); tekstur lempung berpasir (sandy loam); remah; gumpal bersudut (angular blocky) agak lekat; tidak ada perakaran; pori halus sedang; pH 6.5; tidak ada bercak.

Tabel 1. Hasil Analisa Laboratorium Sampel Tanah

\begin{tabular}{|c|c|c|c|c|c|c|c|c|c|c|}
\hline \multirow{2}{*}{\multicolumn{2}{|c|}{ KARAKTERISTIK LAHAN }} & \multirow[b]{2}{*}{ Satuan } & \multicolumn{4}{|c|}{ Sampel 1} & \multicolumn{4}{|c|}{ Sampel 2} \\
\hline & & & \multicolumn{2}{|c|}{ Top Soil } & \multicolumn{2}{|c|}{ Sub Soil } & \multicolumn{2}{|c|}{ Top Soil } & \multicolumn{2}{|c|}{ Sub Soil } \\
\hline \multirow{2}{*}{ Tekstur } & Pasir & \multirow{2}{*}{$\%$} & 58 & \multirow{2}{*}{$\mathrm{SCL}$} & 60 & \multirow{2}{*}{$S C L$} & 57 & \multirow{2}{*}{$\mathrm{SCL}$} & 69 & \multirow{2}{*}{ SL } \\
\hline & Liat & & 24 & & 21 & & 27 & & 9 & \\
\hline Salinitas & & & 0 & & o & & 0 & & 0 & \\
\hline $\mathrm{pH}(1: 2,5)$ & $\mathrm{H} 2 \mathrm{O}$ & & 5,58 & $M$ & 5,42 & $M$ & 6,7 & $\mathrm{~N}$ & 6,32 & AM \\
\hline \multirow[t]{2}{*}{ Bahan Organik } & $\mathrm{N}(\%)$ & $\%$ & 0,15 & $\mathbf{R}$ & 0,15 & $\mathbf{R}$ & 0,1 & $\mathbf{R}$ & 0,13 & $\mathbf{R}$ \\
\hline & $\mathrm{C} / \mathrm{N}$ & & 6 & $\mathbf{R}$ & 4 & SR & 10 & $\mathbf{R}$ & 11 & $\mathbf{R}$ \\
\hline \multirow[t]{2}{*}{ Extract $\mathrm{HCl} 25 \%$} & $\mathrm{P} 2 \mathrm{O} 5$ & \multirow{2}{*}{$\mathrm{mg} / 100 \mathrm{~g}$} & 10 & $\mathbf{R}$ & 15 & $\mathbf{R}$ & 15 & $\mathbf{R}$ & 32 & s \\
\hline & $\mathrm{K} 2 \mathrm{O}$ & & 48 & ST & 52 & ST & 57 & ST & 44 & ST \\
\hline \multirow[t]{2}{*}{ Olsen/Bray } & $\mathrm{P} 2 \mathrm{O} 5$ & \multirow{2}{*}{ ppm } & 4 & SR & 3 & SR & 42 & ST & 22 & s \\
\hline & $\mathrm{K} 2 \mathrm{O}$ & & 25 & s & 24 & s & 38 & ST & 27 & ST \\
\hline \multirow{5}{*}{$\begin{array}{c}\text { NTK (Nilai Tukar } \\
\text { Kation) }\end{array}$} & $\mathrm{Ca}$ & \multirow{7}{*}{$\begin{array}{l}\mathrm{me} / 100 \mathrm{~g} \\
\%\end{array}$} & 4,55 & $\mathbf{R}$ & 2,91 & $\mathbf{R}$ & 5,9 & $\mathbf{R}$ & 2,68 & $\mathbf{R}$ \\
\hline & $\mathrm{Mg}$ & & 0,33 & SR & 0,08 & SR & 0,5 & $\mathbf{R}$ & 0,03 & SR \\
\hline & K & & 0,05 & SR & 0,05 & SR & 0,08 & SR & 0,06 & SR \\
\hline & $\mathrm{Na}$ & & 0,01 & SR & 0,01 & SR & 0,01 & SR & 0,01 & SR \\
\hline & Jumlah & & 4,94 & & 3,05 & & 6,49 & & 2,78 & \\
\hline KTK & & & 3,37 & SR & 14 & $\mathrm{R}$ & 6,85 & $\mathrm{R}$ & 9,01 & $\mathbf{R}$ \\
\hline KB & & & 146,59 & $\mathrm{~s}$ & 21,79 & $\mathrm{~s}$ & 94,74 & ST & 30,85 & $T$ \\
\hline
\end{tabular}

SL: Lempung Berpasir, ST: Sangat Tinggi, T: Tinggi, S: Sedang, R: Rendah, SR: Sangat Rendah, pH: A=Alkalin, AA: Agak Alkalin, N: Netral, M: Masam, AM: Agak Masam, SM: Sangat Masam 
Tanah di lokasi penelitian diklasifikasikan sebagai Kambisol (menurut sistem klasifikasi tanah nasional) atau Ustepts (menurut sistem taksonomi tanah USDA/United State Department of Agriculture), bersolum dalam, drainase agak terhambat, tekstur halus, agak masam, KTK tinggi dan KB tinggi, tersusun dari batuan induk batu liat dan batu pasir. Kambisol merupakan salah satu jenis tanah yang memiliki sifat fisik tanah baik, tetapi kadar N, P, rendah dan bereaksi masam sehingga dapat menghambat pertumbuhan tanaman (Silahooy, 2012). Kambisol (inceptisol) merupakan kombinasi dari beberapa sifat antara lain: tersedia air untuk tanaman lebih dari setengah tahun atau lebih dari 3 bulan berturut-turut dalam musim kemarau (kelembaban ustik), mempunyai satu atau lebih horizon pedogenetik dengan sedikit akumulasi bahan selain karbonat atau silica amorf, bertekstur lebih halus dan pasir geluhan dengan beberapa mineral lapuk, dan mempunyai kemampuan menahan kation fraksi lempung dari sedang sampai tinggi (Saputra, 2018).

Haridjaja Oteng, Dwi Putro Tejo Baskoro, dan Mahartika Setianingsih (2013) mengatakan bahwa tekstur tanah sangat mempengaruhi kemampuan tanah dalam memegang air. Tanah bertekstur liat memiliki kemampuan yang lebih besar dalam memegang air daripada tanah bertekstur pasir. Hal ini terkait dengan luas permukaan adsorptifnya. Semakin halus suatu tekstur akan semakin besar kapasitas penyimpanan air. Hasil analisa di atas menunjukkan bahwa lahan mempunyai tekstur

Hasil analisis lanjutan terhadap beberapa unsur mikro (Tabel 2) menunjukkan bahwa tanah mengalami defisiensi terhadap unsur tembaga (Cu) dan Mangan (Mn), dan telah mencukupi untuk kebutuhan $\mathrm{Fe}$ dan $\mathrm{Zn}$. Walaupun jumlah unsur mikro yang dibutuhkan tidak sebanyak unsur makro, namun unsur tersebut tetap diperlukan dalam proses metabolisme dan pembentukan enzim selama masa TBM. Unsur lempung berpasir. Menurut Hardjowigeno (2007) tanah dengan tekstur ini akan terasa kasar agak jelas, sedikit melekat dan dapat dibuat bola yang mudah sekali hancur.

Hasil pengamatan terhadap sistem drainase menunjukan bahwa sistem drainase internal kurang baik. Hal ini menyebabkan tanah menahan air terlalu banyak pada suatu periode yang lama. Menurut Makarim Abdul Karim dan Ikhwani (2011), setiap tanaman mempunyai kebutuhan air dalam jumlah tertentu pada suatu masa tertentu. Jika tanaman mengalami terlalu banyak air maka akan mengakibatkan ketersediaan oksigen bagi perakaran rendah. Kondisi ini mempengaruhi kehidupan mikroorganisme tanah, seperti cacing dan nematoda. Padahal, menurut Widyati (2013) dan Subowo (2010), keberadaan organisme tanah dapat membantu proses dekomposisi bahan organik untuk meningkatkan kadar $\mathrm{C}$ dan $\mathrm{N}$ tanah. Selain itu, mikroorganisme juga dapat membantu proses pelapukan bahan induk (batuan) yang dapat menyediakan hara penting lain bagi pertumbuhan tanaman.

Hasil pengamatan kedalaman (solum) tanah menunjukan bahwa kedalaman tanah rendah. Kedalaman tanah rendah ini membatasi daya tembus akar untuk mencapai sumber unsur hara yang lebih luas. Pada beberapa kasus, kondisi ini dapat diatasi dengan aplikasi teras gulud dan rorak yang dikombinasikan dengan lubang resapan. Aplikasi ini dapat meningkatkan jumlah daun dan buah (Murtilaksono Kukuh, Witjaksana Darmosarkoro , Edy Sigit Sutarta , Hasril Hasan Siregar, dan Yayat Hidayat, 2009). Tembaga $(\mathrm{Cu})$ berfungsi sebagai aktivator enzim oksidase yang membantu dalam metabolisme asam askorbat dan poliphenol. Sedangkan Mangan (Mn) dibutuhkan dalam proses fotosintesis melalui pembentukan klorofil dan komponen beberapa enzim seperti enzim respirasi dan enzim sintesis protein (Shorrock, 1983 dalam Stevanus Charlos Togi, Jamin Saputra, dan Thomas Wijaya, 2015).

Tabel 2. Hasil Analisis Beberapa Unsur Mikro

\begin{tabular}{|c|c|c|c|c|}
\hline \multirow{2}{*}{ Unsur Mikro } & \multicolumn{2}{|c|}{ Sampel 1 } & \multicolumn{2}{c|}{ sampe1 2 } \\
\cline { 2 - 5 } & Top Soil & Sub Soil & Top Soil & Sub Soil \\
\hline Fe & 11.733 & 9.457 & 23.805 & 18.558 \\
\hline $\mathrm{Cu}$ & $\mathrm{Tt}$ & $\mathrm{Tt}$ & 2 & $\mathrm{Tt}$ \\
\hline $\mathrm{Zn}$ & 13 & 13 & 23 & 18 \\
\hline $\mathrm{Mn}$ & 1 & 1 & 1 & 2 \\
\hline
\end{tabular}

Tt: Tidak Terukur 
Analisis kesesuaian lahan dilakukan dengan mencocokkan karakteristik lahan dengan kriteria kesesuaian lahan yang diperlukan untuk masing-masing komoditas. Analisis kesesuaian lahan secara ringkas disajikan pada Tabel 3.

Tabel 3. Hasil Analisis Kesesuaian Lahan

\begin{tabular}{|c|c|c|c|}
\hline \multirow[b]{2}{*}{ Karakteristik lahan } & \multirow[b]{2}{*}{ Nilai Data ${ }^{13}$} & \multicolumn{2}{|c|}{ Komoditi } \\
\hline & & Jengkol & Petai \\
\hline Temperatur rerata $\left({ }^{\circ} \mathrm{C}\right)$ & 28,5 & 52 & 52 \\
\hline Curah hujan (mm) & 1.800 & 51 & 51 \\
\hline Drainase & Terhambat & 52 & 52 \\
\hline Tekstur & Agak Kasar & $53^{33}$ & $53^{33}$ \\
\hline Ketebalan Gambut (cm) & $\mathbf{0}$ & S1 & 51 \\
\hline $\begin{array}{l}\text { Ketebalan gambut }(\mathrm{cm}) \text {, jika ada } \\
\text { sisipan bahan mineral/ pengkayaan }\end{array}$ & $\mathbf{0}$ & 51 & 51 \\
\hline Kematangan gambut & - & - & - \\
\hline KTK liat (cmol) & $3,37-6,85$ & 52 & 52 \\
\hline Salinitas (dS/m) & o & 51 & 51 \\
\hline Alkalinitas/ESP $(\%)$ & o & 51 & 51 \\
\hline Kedalaman sulfidik (cm) & - & 51 & 51 \\
\hline Lereng $(\%)$ & $8 \%$ & 52 & 52 \\
\hline Bahaya erosi & Rendah & 51 & 51 \\
\hline Genangan & Fo & 52 & 52 \\
\hline Batuan di permukaan (\%) & 0 & 51 & 51 \\
\hline Singkapan batuan $(\%)$ & $\mathbf{0}$ & S1 & 51 \\
\hline KESIMPULAN & & $530 a, \mathrm{rc}^{2}$ & S3oa, $\mathrm{rc}^{2}$ \\
\hline
\end{tabular}

Hasil pencocokan karakteristik lahan dengan kriteria kesesuaian lahan tersebut menunjukkan bahwa tanaman jengkol dan petai mempunyai karakteristik lahan Sesuai Marjinal (S3) dengan faktor pembatas tekstur dan kedalaman tanah (2 faktor pembatas).

Lahan S3 ini menunjukkan bahwa tekstur tanah berpasir dan mengindikasikan bahwa lahan memberikan kemampuan rendah dalam menyediakan unsur hara bagi tanaman karena "kapasitas jerapnya" (absorbtion capacity) rendah terhadap unsur hara penting. Hal ini sesuai dengan hasil penelitian Djajadi, Djajadi; Heliyanto, Bambang; Hidayah, Nurul (2018) yang mengatakan bahwa tekstur tanah berpasir mempunyai daya serap unsur hara yang rendah.

Hasil analisa di atas juga menunjukkan kandungan Karbon (C) dan Nitrogen (N) organik yang sangat rendah. Padahal, keberadaan kedua unsur ini sangat membantu di dalam peningkatan daya serap unsur hara. Djajadi, dkk. (2018) mengatakan bahwa penambahan $5 \%$ tanah liat + $0,8 \%$ bahan organik pada tanah berpasir dapat meningkatkan proporsi makro agregat, kadar unsur hara $\mathrm{C}, \mathrm{N}, \mathrm{P}$, dan $\mathrm{K}$, serta kapasitas daya pegang air tanah. Adrinal, Amrizal Saidi, dan Gusmini (2012) menambahkan bahwa pemberian berbagai jenis mulsa organik seperti jerami padi dan jerami jagung juga dapat memperbaiki sifat fisika dan ciri kimia tanah. Menurut Widiatmaka, S.P. Mulia, M. Hendrisman (2012), jika dilakukan perbaikan lahan, beberapa kelas kesesuaian lahan dapat mengalami kenaikan kelas kesesuaian lahan. Untuk kelas lahan S3 ini, dengan perbaikan lahan dapat mengalami kenaikan kelas dari kelas S3 menjadi S2.

\section{KESIMPULAN}

Kesimpulan dari penelitian ini adalah tingkat kesesuaian lahan untuk tanaman jengkol dan petai adalah Lahan Sesuai Marjinal (S3) dengan faktor pembatas tekstur dan kedalaman tanah (2 faktor pembatas). Untuk menaikan kelas kesesuaian lahan menjadi S2 dapat diberikan bahan-bahan organik dan pembuatan guludan serta rorak dengan lubang-lubang pori untuk resapan air. 


\section{UCAPAN TERIMA KASIH}

Terima kasih yang tak terhingga untuk bapak Heldiansyah yang telah memberikan dukungan teknis dan biaya untuk kegiatan penelitian ini. Demikian juga untuk bapak Iwan Sujana yang telah mendampingi tim survey di lokasi. Semoga hasil penelitian ini dapat lebih memberikan manfaat yang lebih besar kepada masyarakat baik masyarakat sekitar lokasi maupun dunia pendidikan.

\section{DAFTAR PUSTAKA}

Cipto Hendra. (2013, 19 Agustus). Harga Jengkol di Makassar Rp 25.000 Per Ons. Diunduh dari http://regional.kompas.com.

Hardjowigeno, H. Sarwono. (2007). Ilmu Tanah. Jakarta : CV Akademika Pressindo.

Haridjaja Oteng, Dwi Putro Tejo Baskoro, dan Mahartika Setianingsih. (2013). Perbedaan Nilai Kadar Air Kapasitas Lapang Berdasarkan Metode Alhricks, Drainase Bebas, dan Pressure Plate pada Berbagai Tekstur Tanah dan Hubungannya dengan Pertumbuhan Bunga Matahari (Helianthus annuus L.). Jurnal Tanah Lingkungan 15 (2), 52-59. ISSN 1410-7333.

Kementerian Pertanian. 2019. Statistik Pertanian 2018. Kementerian Pertanian RI.

Makarim Abdul Karim dan Ikhwani. (2011). Inovasi dan Strategi untuk Mengurangi Pengaruh Banjir pada Usahatani Padi. Jurnal Tanah Lingkungan 13 (1), 35-41. ISSN 1410-7333.

Murtilaksono Kukuh, Witjaksana Darmosarkoro, Edy Sigit Sutarta, Hasril Hasan Siregar, dan Yayat Hidayat. (2009). Upaya Peningkatan Produksi Kelapa Sawit melalui Penerapan Teknik Konservasi Tanah dan Air. Jurnal of Tropical Soil 14 (2), 135-142. ISSN 0852-257X.

Saputra Fajri. (2018). Analisis Ketersediaan dan Kebutuhan Air Irigasi untuk Pertanian di Kecamatan Padang Ganting Kabupaten Tanah Datar. Jurnal Buana 2 (2), 584-596. E-ISSN : 2615-2630.
Silahooy Ch. (2012). Efek Dolomit dan SP-36 Terhadap Bintil Akar, Serapan N dan Hasil Kacang Tanah (Arachis hypogaea L.) Pada Tanah Kambisol. Jurnal Agrologia 1 (2), 91-98.

Stevanus Charlos Togi, Jamin Saputra, dan Thomas Wijaya. (2015). Peran Unsur Mikro Bagi Tanaman Karet. Warta Perkaretan 34 (1), 11-18.

Subowo G. (2010). Strategi Efisiensi Penggunaan Bahan Organik Untuk Kesuburan Dan Produktivitas Tanah Melalui Pemberdayaan Sumberdaya Hayati Tanah. Jurnal Sumberdaya Lahan 4 (1), ISSN 1907-0799.

Wanto. (2019, 19 Agustus). Jelang Lebaran, Harga Petai Meroket. Diunduh dari http://gatra.com.

Widiatmaka, S.P. Mulia, M. Hendrisman. (2012). Evaluasi Lahan Permukiman Transmigrasi Pola Lahan Kering Menggunakan Automated Land Evaluation System (ALES) Studi Kasus Rantau Pandan Sp-2, Provinsi Jambi. Jurnal Ilmiah Geomatika 18 (2), 144-157. 